\title{
Computer Mediated Communication Dalam Perencanaan Pembangunan Daerah Provinsi Sulawesi Barat
}

\author{
Arianto, Tuti Bafiarti \\ e-mail : arianto@unhas.ac.id; tutibahfiarti@unhas.ac.id \\ Universitas Hasanuddin, Jalan Perintis Kemerdekaan Km. 10, Makassar Indonesia
}

Submitted: 26 Februari 2020 Revised: 18 Maret 2020 Accepted: 01 April 2020

\begin{abstract}
Abstrak
Computer Mediated Communication (CMC) merupakan bentuk kegiatan komunikasi melalui penggunaan media komputer berjaringan internet. Penggunaan $C M C$ untuk perencanaan pembangunan bersifat digital yaitu menggunakan aplikasi e-planning sebagai inovasi dari media informasi dalam penyusunan dokumen perencanaan pembangunan daerah berbasis elektronik. Pemerintah Provinsi Sulawesi Barat sebagai bagian dari provinsi di Indonesia telah menggunakan media teknologi informasi ini. Tujuan penelitian adalah untuk memberikan gambaran penggunaan Computer Mediated Communication (CMC) berbasis website e-planning dalam menyusun dan menetapkan proritas perencanaan daerah. Metode penelitian yang digunakan merujuk pada tipe penelitian kualitatif deskriptif merujuk pada jenis penelitian studi kasus. Jenis data yang digunakan, berupa data primer dan sekunder dari berbagai sumber. Data dikumpulkan menggunakan instrumen utama wawancara mendalam dan observasi kepada sejumlah informan penelitian yang diperoleh berdasarkan teknik purposive sampling. Selanjutnya data yang telah terkumpul dianalisis secara kualitatif untuk penyimpulan secara induktif. Hasil penelitian menemukan bahwa Computer Mediated Communication (CMC) dalam perencanaan pembangunan daerah Provinsi Sulawesi Barat menggunakan e-planning berbasis website. Penggunaan aplikasi e-planning dalam bentuk fitur-fitur digunakan untuk penginputan dokumen-dokumen RPJMD, Renstra, Pokir, dan hasil Musrembang. Selanjutnya, tersedia fitur monitoring dan kontrol, terintegrasi dalam penentuan perogram penganggaran. Akhirnya sarana dalam memberikan informasi untuk proses finalisasi penentuan pengambilan keputusan proritas pelaksanaan perencanaan pembangunan daerah berbasis kepentingan publik.
\end{abstract}

Kata kunci: CMC, E-planning, Perencanaan Daerah, Provinsi Sulawesi Barat

\section{Computer Mediated Communication in Regional Development Planning of West Sulawesi Province}

\begin{abstract}
Computer Mediated Communication (CMC) is a form of communication activities through the use of computer media with internet networks. The use of CMC for digital development planning is to use e-planning applications as innovations from information media in the preparation of electronic-based regional development planning documents. The West Sulawesi Provincial Government as part of the provinces in Indonesia has used this information technology media. The research objective is to provide an overview of the use of e-planning website based Computer Mediated Communication (CMC) in compiling and setting regional planning priorities. The research method used refers to the type of descriptive qualitative research refers to the type of case study research. The type of data used is primary and secondary data from various sources. Data were collected using the main instruments in-depth interviews and observations to a number of research informants obtained based on purposive sampling techniques. Furthermore, the data collected has been analyzed qualitatively for inductive inference. The results of the study found that Computer Mediated Communication (CMC) in regional development planning in West Sulawesi Province uses website-based eplanning. The use of e-planning applications in the form of features is used for the input of RPJMD, Renstra, Pokir, and Musrembang documents. Furthermore, there are monitoring and control features, integrated in the determination of the budgeting program. Finally, the means to provide information for the process of finalizing the decision making is the priority of the implementation of regional development planning based on public interests.
\end{abstract}


Keywords: CMC, E-planning, Regional Planning and Province of West Sulawesi

PENDAHULUAN

Perkembangan teknologi informasi dan komunikasi di era digital memberikan peluang bagi pengaksesaan, pengelolaan, dan pendayagunaan informasi secara cepat dan akurat sesuai skala prioritas kebutuhan pembangunan suatu daerah. Seiring perkembangan teknologi komunikasi dan informasi, kehadiran jaringan internet membantu komunikasi pemerintah daerah, instansi lainnya dan masyarakat. Kemajuan media Teknologi Informasi dan Komunikasi (TIK) telah menghadirkan program yang memudahkan kehidupan bermasyarakat dari berbagai aspek, seperti ekonomi, budaya, sosial, pelayanan pemerintahan dan lain-lain.

Konsekuensi logis untuk pengembangan suatu sistem Teknologi Informasi dan Komunikasi (TIK) digital, khususnya dalam penyusunan perencanaan pembangunan daerah. Misalnya, perencanaan pembangunan berbasis media teknologi website. Penggunaan aplikasi website sebagai sistem perencanaan untuk mendukung upaya sinergi perencanaan antara pemerintah pusat dan pemerintah daerah dalam penyusunan rencana kerja pemerintah. Aplikasi website dapat diakses melalui internet, dikenal dengan sebutan Computer Mediated Communication (CMC). Secara konseptual Computer Mediated Communication (CMC) merupakan bentuk pertukaran infromasi yang terjadi melalui penggunaan dua atau lebih komputer berjaringan internet. Format yang diterapkan dalam bentuk komunikasi berbasis teks seperti pesan dokumen.
Proses perencanaan pembangunan juga dituntut sejalan dengan prinsip tata pemerintah yang baik (good governace). Adapun untuk menindaklanjuti ini pemerintah daerah berkewajiban untuk mengembangkan dan memanfaatkan kemajuan teknologi informasi. Penggunaan sistem informasi (e-planning) pada perencanaan tingkat daerah tercantum pada Permendagri Nomor 86 Tahun 2017 pasal 14 ayat (3); yang menyebutkan penyusunan RPJPD, RPJMD, dan RKPD dilakukan berbasis $e$ planning dan Undang-undang Nomor 23 Tahun 2014 tentang Pemerintahan Daerah pasal 274 dan pasal 391 (Wayan D. J, 2019)

Pemerintah Provinsi Sulawesi Barat merupakan provinsi di Indonesia yang telah menggunakan media teknologi informasi ini. Format mengacu pada proses pertukaran pesan di mana pesan disampaikan melalui perantaraan media seperti komputer internet. Penggunaan $C M C$ untuk perencanaan pembangunan bersifat digital menggunakan aplikasi $e$ planning sebagai inovasi dari media informasi dalam penyusunan dokumen perencanaan pembangunan daerah berbasis elektronik. Aplikasi e-planning disosialisasikan oleh Badan Perencanaan Pembangunan Daerah (Bappeda) Pemerintah Provinsi Sulawesi Barat pada 2015 dan pertama kali digunakan untuk penyusunan Rencana Kerja Pemerintah Daerah (RKPD) (Kalalembang, 2019). Media teknologi informasi digital $e$ planning diakses di situs web http;//bappedesulselbar.eplanning9.com/ ini sebagai pusat data perencanaan 
pembangunan, meliputi penginputan, mengokordinasikan penyusunan, pengendalian, dan evaluasi pelaksanaan rencana pembangunan daerah.

Aplikasi e-planning dengan pendekatan $\quad C M C$ merupakan pengaplikasian teknologi komunikasi dan informasi digunakan saat ini di lingkungan pemerintahan pusat maupun daerah. Kebaruan penelitian ini bahwa sistem teknologi informasi e-planning ini sudah diimplementasikan secara cepat dan tepat, termasuk di Propinsi Sulawesi Barat.

Penggunaan $C M C$ digital $e$ planning ini merupakan suatu usaha yang sistematis dan kontinu dalam mengorganisir aktivitas manusia terhadap upaya penggunaan sumber daya komunikasi secara efisien guna merealisasikan kebijakan-kebijakan terkomunikasikan. Misalnya, sebuah dokumen tertulis yang menggambarkan apa yang harus dilakukan berhubungan dengan komunikasi dalam pencapaian tujuan, dengan cara apa sehingga tujuan tersebut dapat dicapai, dan kepada siapa program komunikasi itu ditujukan, dengan peralatan dan dalam jangka waktu berapa lama hal itu bisa dicapai, dan bagaimana cara mengukur (evaluasi) hasil-hasil yang diperoleh dari program tersebut (Wijaya, Ida Suryani, 2015).

Seperti hasil penelitian dilakukan Aisyah \& Chandra, (2018) dalam judul Pemanfaatan Media Online Beritajakarta.id. Publikasi Program Kerja Pemprov DKI Jakarta, menemukan bahwa penggunaan website memberikan informasi mendalam tentang produk dan layanan Pemerintah Provinsi DKI Jakarta. Hal itu yang dilakukan oleh website beritajakarta.id dalam memberikan informasi, produk dan layanan kepada masyarakat. Bentuk penerapan nyata yang dilakukan oleh Humas Pemprof DKI melalui website beritajakarta.id adalah menyampaikan informasi yang merupakan implementasi dari kebijakan dan program kerja Pemerintah Provinsi DKI Jakarta, dengan karakteristik informasi dari sumber yang dipercaya. Dalam mempublikasikan suatu kegiatan, Pemerintah Provinsi DKI Jakarta dalam menyampaikan proses selama kegiatan berlangsung, dari sebelum hingga sesudah pelaksanaan kegiatan tersebut dari sudut SKPD (Satuan Kerja Perangkat Daerah). Karakteristik pertama yaitu disseminate information, Pemerintah Provinsi menerapkan beritajakarta.id dalam fungsinya menyebarkan informasi publik. Hasil penelitian ini menemukan bahwa website bukan hanya sekedar media teknologi digital penyebar informasi saja, melainkan juga sebagai ruang interaktif antara institusi/perusahan dengan masyarakat. Hasil penelitian lain juga menemukan bahwa Sistem Informasi Perencanaan, Monitoring dan Evaluasi Pembangunan (SIMRAL) atau yang biasa disebut e-planning sebagai sarana pengolahan data elektronik, melaksanakan pengumpulan bahan dan penyusunan pedoman dan petunjuk teknis serta evaluasi penyelenggaraan urusan pemerintahan daerah yang mengacu pada peraturan perundang-undangan yang bersesuaian dengan fungsinya yang dalam hal ini adalah Peraturan Menteri Dalam Negeri Nomor 54 Tahun 2010 (Sani, B. F., Harianto, H., \& Falatehan, A. F, 2019).

Demikian halnya penggunaan CMC informasi e-planning penuntun kegiatan usaha atau kegiatan komunikasi sepanjang program dilaksanakan. Informasi hadir berupa dokumen kerja yang selalu diperbaharui secara periodik 
sesuai dengan perubahan kebutuhan khalayak. Data dan informasi tersebut merupakan aset bagi proses pembangunan yang dilaksanakan oleh pemerintah daerah dan dapat menjadi referensi bagi para pimpinan dalam pengambilan keputusan setiap aktifitas. CMC sebagai standarisasi memantau seluruh program pembangunan yang telah, sedang, dan akan dilaksanakan. Dalam perkembangan sistem informasi $e$ planning diharapkan dapat menjadi sebuah pusat data dan informasi yang menyeluruh mengenai pembangunan daerah yang dapat diakses secara langsung oleh siapa pun dengan tingkatan akses sesuai kepentingan masing-masing.

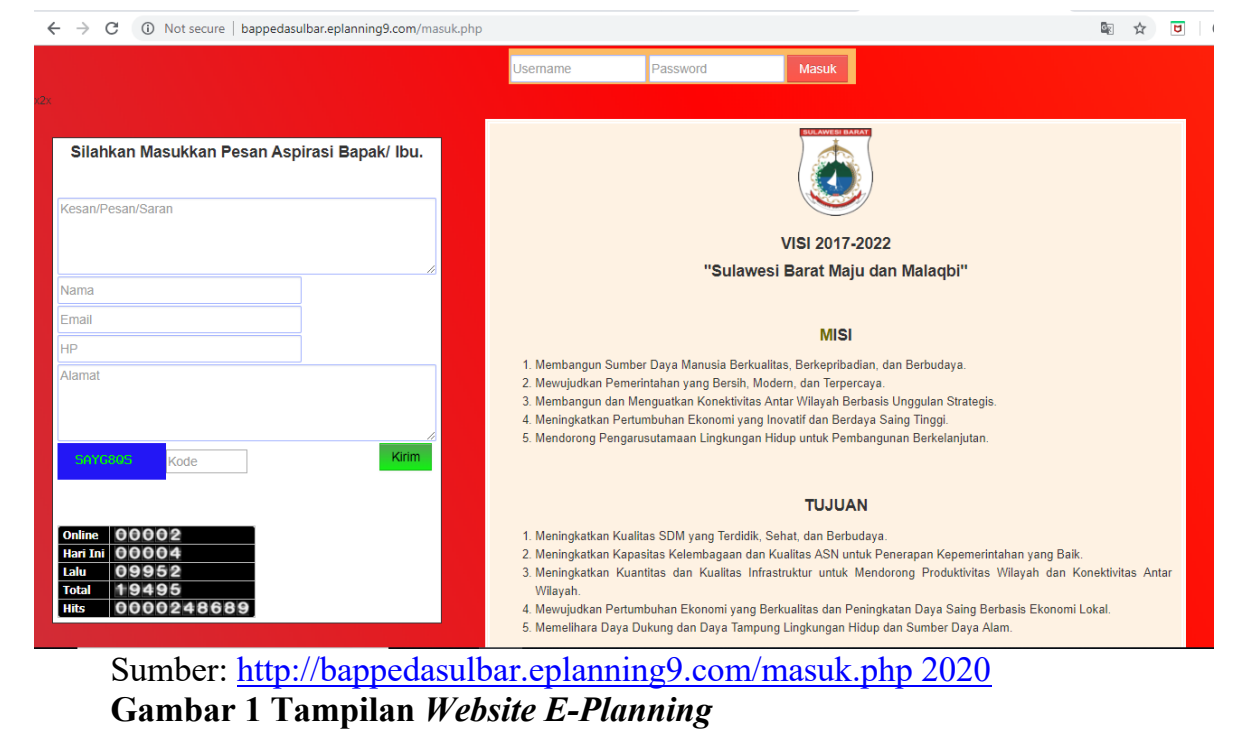

Aplikasi e-planning ini kerap digunakan sebagai suatu media informasi digital untuk melakukan penyusunan perencanaan pembangunan di daerah, khususnya untuk penyusunan rencana pembangunan berbasis good government. Namun demikian, dalam pelaksanaan penyusunan perencanaan pembangunan daerah. Pemerintah Provinsi Sulawesi Barat sering menghadapi kendala dalam menyusun kebijakan ataupun program dalam peningkatan tata kelola pemerintahan yang lebih baik. Misalnya, kendala dalam penataan dan pengelolaan pemerintahan yang memiliki cakupan aspek yang luas dan kompleks, sehingga dalam proses pembangunan membutuhkan banyak informasi mengenai aspek strategis dalam menetapkan program prioritas sebagai langkah awal perbaikan kinerja pemerintahan. Untuk itu, dalam penataan dan pengelolaan pemerintahan yang baik diperlukan akuntabilitas dan transparansi dalam proses perencanaan pembangunan, dengan memanfaatkan sistem informasi perencanaan pembangunan (e-planning) dalam kerangka e-government (Kalalembang, 2019).

Aspek teknis penggunaan media informasi digital ini, sering terjadi inkonsistensi antara dokumen perencanaan dan dokumen penganggaran, hal ini terbukti pada dokumen Renja Akhir yang merupakan dokumen perencanaan dan Dokumen Pelaksanaan Anggaran (DPA) Tahun 2019 Dinas Komunikasi, Informatika, Persandian dan Statistik yang merupakan salah satu OPD lingkup Pemerintah Provinsi Sulawesi Barat menunjukkan jumlah program, kegiatan, 
dan anggaran yang tidak konsisten. Hal ini akibat kurangnya informasi yang diperoleh di awal perencanaan sehingga proses perencanaan tidak terukur. Penyusunan rencana, dukungan data, serta capaian kinerja dan anggaran, masih kurang efektif dan efesien. Hal ini terjadi karena aplikasi e-planning masih belum terintegrasi dengan sistem informasi lainnya yang merupakan bagian dari sumber informasi data untuk saling melengkapi dalam proses perencanaan pembangunan. Perencanaan dan penganggaran dilakukan secara terpisah, yakni perencanaan program dilakukan Bappeda dan penganggaran di Bagian Keuangan. Oleh karena itu, ke depan, proses penginputan dokumen dan anggaran sudah harus terintegrasi melalui sistem elektronik (Zainuddin, 2018.). Diperlukan analisis deskriptif secara mendalam penggunan $C M C$ berbasis website e-planning yang baik dalam penyusunan perencanaan pembangunan di daerah, khususnya untuk penyusunan rencana pembangunan mengarah kepencapaian tujuan dalam mendesain proritas perencanaan pembangunan daerah bedasarkan azas good government.

Media teknologi informasi digital harus sesuai dengan karakteristik penerima pesan. Di era digital berbasis internet menjadi faktor yang vital dalam kehidupan. Media-media berbasis internet (digital) ini juga telah digunakan sebagai salah satu platform untuk mendistribusikan program-program perencanaan pembangunan daerah. Saat ini, media lama harus bisa bersaing dengan atau memanfaatkan media baru atau new media/digital media. Seperti penjelasan Biagi (dalam Saptya Mohamad dan Narotama Mahameruaji, (2005) bahwa media digital adalah :
"The term digital media is used to describe all forms of emerging communications media. Digital media, sometimes called new media, combine text, graphics, sound and video using computer technology to create a product that is similar to, but clearly different from, traditional media, often called old media. Old media are the seven traditional, original mass media-print (books, newspapers and magazines); audio (recordings and radio); and video (movies and television)"

Kehadiran media teknologi digital berjarigan internet, kini seluruh dunia bisa terhubung secara cepat tanpa harus memperhitungkan faktor ruang, jarak, dan waktu. Hal ini diungkapkan oleh Marshall McLuhan mengenai konsep global village, manusia-manusia di dunia ini dapat saling terhubung dengan cepat sehingga terbentuk sebuah desa global berkat teknologi informasi dan komunikasi yang berkembang pesat. Di dalam global village ini terdapat masyarakat berjejaring atau network society. Penjelasan Rustam (2017) mengisyaratkan bahwa network society merupakan salah satu konsep yang banyak digagas para ahli untuk menggambarkan fenomena aktivitas komunikasi masyarakat melalui penggunaan Information and Communication Technology (ICT) atau dikenal juga dengan TIK (Saptya Mohamad dan Narotama Mahameruaji, 2019)

Pertumbuhan dramatis internet telah secara nyata mengubah pola interaksi dalam semua aspek kehidupan. Perubahan dramatis ini memunculkan pertanyaanpertanyaan dasar tentang dari mana asal media baru. Pemahaman Roger Fidler telah merepresentasikan sebuah gagasan 
yang menarik yakni mediamorfosis. Mediamorfosis dapat membantu memahami jenis perubahan di bidang media. Misalnya, menurut Fidler (Saptya Mohammad dan Narrotama Mahameruaji, 2019) mendefinisikan mediamorfosis sebagai "bentuk media komunikasi, biasanya disebabkan oleh interaksi kompleks dari kebutuhan-kebutuhan penting, tekanan-tekanan kompetitif dan politis, dan inovasi-inovasi sosial dan teknologis".

Pemerintah Provinsi Sulawesi Barat menghadirkan website resmi $e$ planning, sebagai media informasi digital berbasis $C M C$, agar pemerintah daerah dapat memberikan informasi program perencanaan pembangunan pemerintah provinsi kepada masyarakat dikenal dengan kata website. Website merupakan ikon paling dominan dalam dunia maya aplikasi ini dinamis dan paling banyak dimanfaatkan oleh manusia. Konsep awal dari website adalah penggunaan hypertext (dokumen dalam bentuk elektronik yang saling dikaitkan dengan cara tertentu), tetapi seiring berkembangnya teknologi, hypertext berubah menjadi www. Bukan sekedar mengirim text, hypertext juga mampu menyimpan gambar, suara, maupun video, dan mulai berkembang ke arah multimedia (Nugroho dan Fikri Saleh; 2019)

\section{Website resmi e-planning} digunakan untuk melakukan komunikasi antar dua orang atau lebih yang dapat saling berinteraksi melalui komputer yang berbeda, untuk mendapatkan informasi yang dibutuhkan publik dalam perencanaan pembangunan. Hal ini juga merupakan bagian dari kebijakan informasi publik yang telah menjadi program pemerintah pusat. Pengunaan website situs e-planning dapat diakses hanya melalui sistem antar perangkat komputer untuk lalu lintas data, itulah dinamakan Local Area Network (LAN).

Istilah LAN menghubungkan komputer-komputer dalam area tertentu, seperti kantor, sekolah, atau warung internet. Area jaringan sangat luas, yaitu seluruh dunia. Komputer yang terhubung melalui jaringan dan saling berkomunikasi dengan waktu dan wilayah tak terbatas (Darma \& Shenia, 2009). Merujuk pada penggunaan komunikasi bermedia komputer atau CMC, dalam Thurlow, Lengel, \& Tomic, (2004) dan Wong Sabrina (2007), menyatakan bahwa :

Computer Mediated Communication is a process of human communication via computers, involving people, situated in particular contexts, engaging in processes to shape media for variety of purposes. As a style of communication between two or more individual people through a technological medium such as the internet or connected network software.

Penggunaan $C M C$ sebagai metode untuk menciptakan jaringan digital dan juga termasuk interaksi manusia, yang berbasis teks simbolis, dan juga diarahkan atau difasilitasi melalui teknologi berbasis digital. Penggunaan $C M C$ dalam sistem pemerintahan meliputi kerja sama, interaktif, dan berkesinambungan antara pemerintah daerah dan masyarakat dalam menyebarluaskan informasi-informasi program perencanaan pembangunan.

Merujuk pada hal tersebut $C M C$ dapat mencakup hampir semua penggunaan komputer termasuk itu beragam aplikasi sebagai program analisis statistik, sistem penginderaan jauh, dan program pemodelan keuangan, semuanya 
sesuai dengan konsep komunikasi manusia. Seperti dijelaskan, Gerry Santoro dan John December (dikutip Crispin Thurlow, Laura Lengel and Alice Tomic, (2004:15) berikut penjelasannya:

....CMC can encompass virtually all computer uses including such diverse applications as statistical analysis programs, remote-sensing systems, and financial modelling programs, all fit within the concept of human communication..... Computer Mediated Communication is a process of human communication via computers, involving people, situated in particular contexts, engaging in processes to shape media for a variety of purposes.... CMC is communication that takes place between human beings via the instrumentality of computers.

$C M C$ merupakan bentuk komunikasi antar manusia menggunakan media komputer. CMC memberikan pengaruh sosial yang berbeda akibat dari teknologi komunikasi yang didukung oleh komputer. Meskipun dalam penggunaan aplikasi melalui komputer dan teknologi digital dalam prakteknya juga melibatkan komunikasi antarpribadi manusia. Banyak studi yang melibatkan internet dengan pengguna jaringan sosial (social network) yang didukung oleh perangkat lunak sosial (social software). (Thurlow, C., Lengel, L., \& Tomic, A.; 2004)

Determinisme teknologi adalah teori reduksionis yang bertujuan untuk menyediakan hubungan sebab akibat antara teknologi dan sifat masyarakat. Ia mencoba menjelaskan kepada siapa atau apa yang bisa memiliki kekuatan pengendali dalam urusan manusia. Teori ini mempertanyakan sejauh mana pemikiran atau tindakan manusia dipengaruhi oleh faktor teknologi. Istilah "determinisme teknologi" diciptakan oleh
Thorstein Veblen dan teori ini berputar di sekitar proposisi bahwa teknologi dalam masyarakat tertentu mendefinisikan sifatnya. Teknologi dipandang sebagai kekuatan pendorong budaya dalam suatu masyarakat dan menentukan arah sejarahnya.

Pandangan teori ini merujuk perubahan sosial yang dikontrol oleh teknologi komunikasi dan media dan perkembangan teknologi. Masyarakat moderen karena informasi terbaru sebagai akibat dari perkembangan inovasi, teknologi baru, sosial, implikasi politik. Seperti dijelaskan Thomas Hauer (2017) bahwa:

technological determinism, any social changes are controlled by the technology, technological development, communications technology and media. The modern information society arises as a result of the development of innovations, new technologies and their social and political implications.....The technology does not determine the society, the technology is the society.

Determinisme teknologi dalam upaya peningkatan pelayanan merujuk pada perubahan cara berkomunikasi, membentuk cara berpikir, berperilaku, dan bergerak ke abad teknologi dalam kehidupan manusia. Pendekatan teori determinisme menjelaskan bahwa penemuan atau perkembangan teknologi komunikasi merupakan faktor yang mengubah kebudayaan manusia. Perintis teori ini, McLuhan, menjelaskan bahwa eksistensi manusia ditentukan oleh perubahan model komunikasi (Mubarok, 2011). Dimulai cara berpikir, budaya dibentuk, dan cara berkomunikasi. Tahapan meliputi: (1) penemuan dalam teknologi komunikasi menyebabkan 
perubahan budaya. (2) perubahan ragam berkomunikasi dalam kehidupan manusia; (3) terciptanya peralatan atau media untuk berkomunikasi dan akhirnya media digunakan untuk berkomunikasi itu membentuk atau mempengaruhi kehidupan sendiri (Mubarok, 2011).

Kehadiran $C M C$ memungkinkan dan mendorong komunikasi dua arah dan interaktif, horizontal maupun vertikal, terhubung bukan terisolasi, tidak lagi dimonopoli oleh professional, kontennya sangat beragam, tunduk kepada sedikit kontrol sosial, kurang bersifat kelembagaan, dan jenis serta arahnya tidak menentu (McQuail, 2011). CMC berbasis website e-planning, merupakan media dan teknologi baru dan karenanya memiliki faktor determinasi. Seperti sifat teknologi dan arah perubahan yang tidak bermasalah atau sebelum ditentukan (mungkin tergantung pada logika teknis atau ekonomis) dan teknologi telah diperlukan dan menentukan dampak pada pekerjaan, kehidupan ekonomi dan masyarakat secara keseluruhan, perubahan teknologi dengan demikian menghasilkan perubahan sosial dan organisasi.

\section{METODE PENELITIAN}

Penelitian ini menggunakan desain penelitian deskriptif kualitatif. Penelitian ini memilih pendekatan deskriptif kualitatif untuk menggambarkan pemahaman pemangku kepentingan dalam memanfaatan $e$ planning dalam perencanaan pembangunan daerah. Jenis penelitian studi kasus digunakan untuk memberikan pemahaman dan memperoleh kompleksitas satu kasus tentang pemanfaatan e-planning sebagai media komunikasi berjaringan online berdasarkan pengalaman orang yang menjadi latarbelakang dari peristiwa tersebut. Studi kasus digunakan juga karena peneliti menginginkan pemahaman lebih baik pada kasus khusus yang diteliti.

Lokasi penelitian ini dilaksanakan instansi pemerintah daerah propinsi yaitu Kantor Badan Perencanaan Pembangunan Daerah Provinsi Sulawesi Barat dan Organisasi Perangkat Daerah (OPD) lingkup Pemerintah Provinsi Sulawesi Barat. Kantor ini beralamat di Kompleks Perkantoran Gubernur Sulawesi Barat Jalan Pattana Endeng, Mamuju Kode Pos 91511.

Kemudian untuk informan dalam penelitian ini dipilih dengan menggunakan teknik purposive sampling, yaitu pemilihan informan penelitian secara sengaja dengan maksud peneliti memilih informan yang memiliki pengalaman dan mampu memberikan informasi secara komprehensif yang berkaitan dengan permasalahan yang sedang diteliti. Kriteria informan dalam penelitian ini yaitu memahami dan sebagai pengguna aplikasi e-planning serta informan yang memiliki keterkaitan dalam pengambilan kebijakan pada bidang perencanaan pembangunan daerah yang didukung dengan pengembangan teknologi informasi dan komunikasi. Informan dipilih dalam penelitian ini berjumlah 6 (enam) orang; Kepala Sub Bidang Perencanaan Makro Badan Perencanaan Pembangunan Daerah, Kepala Sub Bagian Program dan Keuangan Dinas Pekerjaan Umum dan Penataan Ruang, Kepala Sub Bagian Program dan Keuangan Dinas Lingkungan Hidup, 2 orang ASN Bidang 
Perencanaan Makro Bappeda sebagai admin aplikasi e-planning.

Pengumpulan data dapat dilakukan dalam berbagai sumber yaitu pengumpulan data dapat menggunakan sumber primer dan sumber sekunder. Sumber data primer adalah sumber data yang langsung memberikan data kepada pengumpul data, misalnya, hasil wawancara dengan pemangku kepentingan serta observasi terhadap kegiatan pemanfaatan e-planning dalam perencanaan pembangunan daerah. Sumber data sekunder merupakan sumber yang tidak langsung memberikan data kepada pengumpul data, misalnya buku, jurnal ilmiah, arsip-arsip, peraturan pemerintah maupun peraturan daerah, dan media online. Untuk instrumen yang digunakan untuk mengumpulkan data mencakup wawancara mendalam (indepth interview), observasi non partisipan, dan dokumentasi.

Untuk analisis data secara kualitatif. Analisis data ini dimulai pada pengumpulan data berlangsung dan setelah selesai pengumpulan data dalam periode tertentu. Pada saat wawancara, peneliti sudah melakukan analisis terhadap jawaban yang diwawancarai.

\section{HASIL DAN PEMBAHASAN}

Penggunan $C M C$ berbasis website e-planning dalam penyusunan perencanaan pembangunan di daerah, khususnya untuk penyusunan rencana pembangunan mengarah kepencapaian tujuan. Pemerintah Provinsi Sulawesi Barat menggunakan sistem e-planning sebagai media informasi teknologi website berntegrasi, yaitu e-planning berbasis SSH (Standar Satuan Harga) dan ASB (Analisis Standar Biaya) dan, e-planning terintegrasi dengan e-budgeting bekerja sama BPKP dalam pengembangan aplikasi Simda Perencanaan (e-planning).

Hasil penelitian menunjukkan bahwa $C M C$ teknologi digital berbasis web (e-planning atau Simda Perencanaan) sudah mulai digunakan sejak tahun 2019 untuk menyusun perencanaan tahun anggaran 2020 dengan sistem yang terintegrasi antara perencanaan dan penganggaran. Karateristik website $e$ planning atau Simda Perencanaan (Simdan) adalah sebagai berikut :

Tabel 1 Karateristik E-planning atau Simda Perencanaan (Simdan)

\begin{tabular}{lc}
\hline \multicolumn{1}{c}{ Karateristik } & E-planning /Simdan \\
\hline Online berbasis Web (CMC) & $\sqrt{ }$ \\
Menggunakan database & $\sqrt{ }$ \\
Dimonitorin dan di kontrol & $\sqrt{ }$ \\
Terintegrasi dalam Perencanaan dan & $\sqrt{ }$ \\
Penganggaran & $\sqrt{ }$ \\
Terintegrasi aplikasi lainnya & \\
\hline
\end{tabular}

\begin{tabular}{lll}
\multicolumn{1}{c}{ Aplikasi e-planning/Simdan } & penyusunan perencanaan. Sistem \\
memudahkan dalam & menyusun & Informasi Perencanaan Pembangunan \\
perencanaan secara elektronik. Selain itu, & Daerah (e-planning) adalah sebuah alat \\
dengan e-planning, dapat mencegah & penyusunan RPJMD, Renstra, RKPD, \\
kesalahan input ataupun perubahan- & Renja Pemerintah Daerah agar dapat \\
perubahan yang dilakukan oleh orang yang & terselesaikan dengan mudah, cepat, tepat \\
tidak bertanggung jawab dalam proses & dalam penyusunan dokumen perencanaan
\end{tabular}


sebagaimana diamanatkan dalam

Permendagri No. 86 Tahun 2017. Organisasi Perangkat Daerah (OPD) di Provinsi Sulawesi Utara yang berikan kewenangan dalam menyusun perencanaan pembangunan Daerah Pemerintah dikutip dalam Harry P, Edward F.T., Kalalo.Y, (2018). Hal ini terkait yang dikemukakan oleh informan Bapak ATW dalam wawancara menyatakan sebagai berikut ini:

"Menggunakan e-planning dan ebudgeting karena sebenarnya sistem online ini kan suatu alat ji, sistemnya aplikasinya di komputer. Memudahkan karena kalau misalnya kita masih sistem manual konvensional kita kan OPD itu, karena begini RKPD itu kan bagian-bagiannya renja $O P D$, RKPD itu secara keseluruhan rencana kerja dari semua OPD jadi kalau misalnya kita masih sistemnya konvensional atau manual, otomatiskan OPD itu membuat secara manual misalnya di Exel atau di Word untuk menyusun rencana kerjanya baru disampaikan ke Bappeda, itu masih manual tapi karena adanya sistem itu tidak lagi OPD, apa yang terinput dalam sistem database atau akun usernamenya OPD itu akan muncul di akunnya super admin yang di bappeda. Dan itu mengeliminasi bias-bias yang bisa terjadi seperti adanya penambahan program ini juga terintegrasi dengan aplikasi lainnya. Kontrol, verifikasi dan editing, terhindar kepentingan lain.

Dalam penyusunan perencanaan pembangunan yang efektif, $C M C$ sistem perencanaan berbasis elektronik penyampaian informasi perencanaan daerah dapat dilakukan secara berkala melalui dokumen tertulis dan media lainnya. $C M C$ memberikan informasi perencanaan pembangunan daerah serta dapat mengubah cara berpikir dan bekerja dalam efektivitas perencanaan pembangunan daerah. Penyusunan rencana kerja perangkat daerah pada lingkup Pemerintah Provinsi Sulawesi Barat.

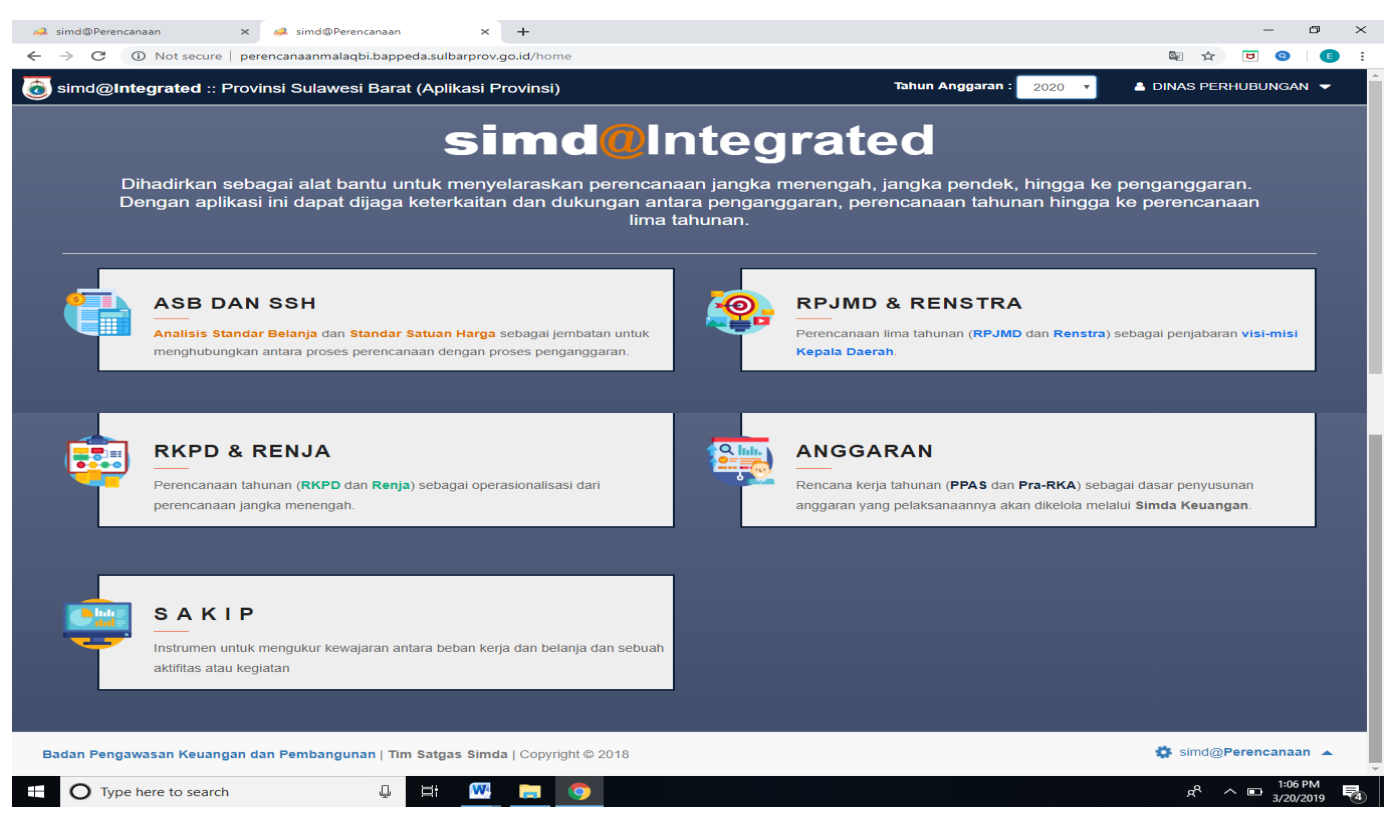

Sumber : http://bappedasulbar.eplanning9.com/masuk.php 2020

Gambar 2 Menu Utama Aplikasi 
CMC berbasis website e-planning atau Sindam digunakan dalam efektivitas perencanaan pembangunan daerah. Untuk penyusunan rencana kerja perangkat daerah pada lingkup Pemerintah Provinsi Sulawesi Barat, sebagai berikut:

1. Penginputan perencanaan dalam database

Proses awal penggunaan $C M C e$ planning (Simdan) adalah penginputan data-data dokumen perencanaan dalam sistem database. seperti dokumen RPJMD, Renstra, rancangan awal RKPD, rancangan awal Renja OPD, usulan dari Pemerintah Kabupaten, dan Pokok Pikiran DPRD yang merupakan hasil dari penjaringan aspirasi masyarakat oleh anggota DPRD. Bappeda provinsi menginput RPJMD dan SIPPD ke sistem database. Kemudian, OPD juga menginput dokumen Renstra pada aplikasi Simda Perencanaan.dan Renja. Pemerintah Kabupaten menginput usulan rencana kerja pada web e-planning, demikian juga Pokir sehingga semua dokumen tersimpan di database.

Dokumen perencanaan bersumber dari RPJMD dan Renstra OPD untuk menentukan RKPD, yang mana OPD menentukan program dan kegiatan prioritas untuk mendukung rencana kerja Pemerintah Daerah Provinsi Sulawesi Barat yang berpedoman pada janji-janji kerja Gubernur. Setelah RPJMD dan Renstra diinput ke dalam aplikasi e-planning, maka setiap OPD akan menyusun rancangan awal rencana kerja yang berisikan program dan kegiatan yang berdasarkan data RPJMD dan Renstra.

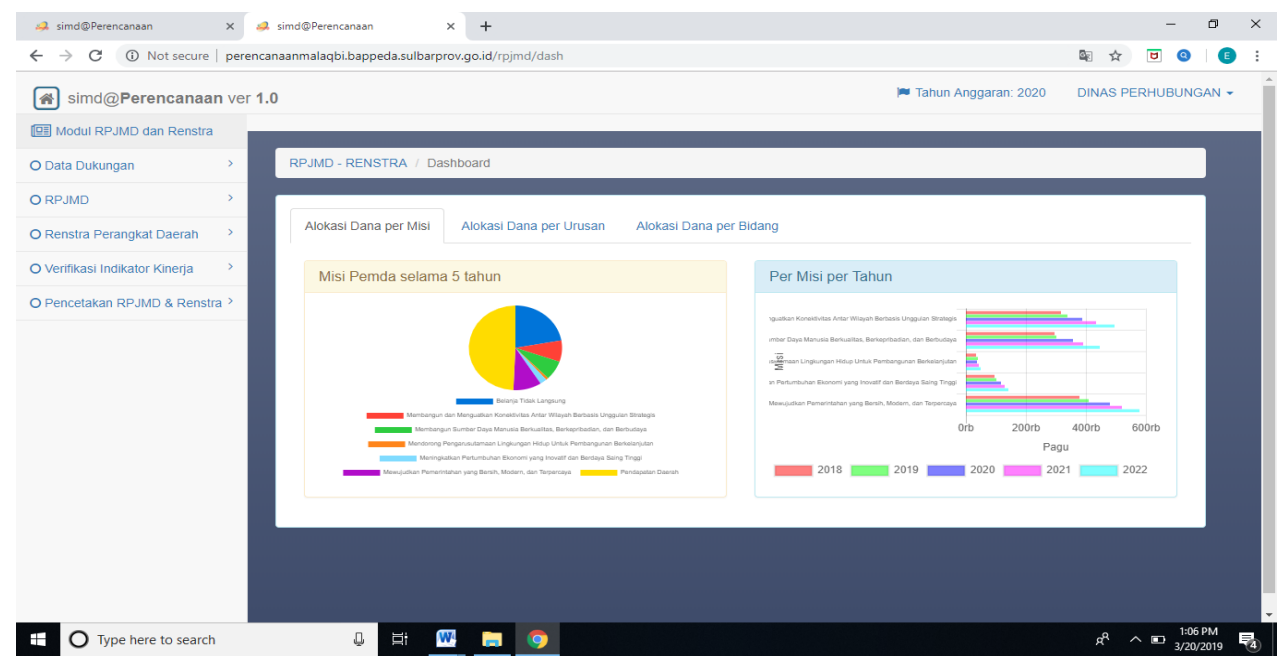

Sumber: http://bappedasulbar.eplanning9.com/masuk.php 2020

\section{Gambar 3 Fitur Penginputan RPJMD dan Renstra}

Kemudian pihak Bappeda juga menyusun rancangan awal RKPD yang berdasarkan data RPJMD dan Renstra dalam aplikasi fitur e-planning, yang kemudian dari OPD akan menyusun rancangan awal renja berdasarkan data rancangan awal RKPD tersebut. Hal ini terkait dengan aplikasi e-planning yang memiliki sistem sinkronisasi yang terhubung antar dokumen perencanaan jangka menengah dan tahunan. 
Proses penginputan Renstra ke dalam aplikasi e-planning dilaksanakan pada aplikasi Simda Perencanaan oleh setiap OPD. Untuk aplikasi e-planning sebelumnya (SIPPD) penginputan pada sistem dilakukan oleh Bappeda. Pihak OPD hanya memberikan rancangan Renstra secara manual kepada Bappeda. Seperti dijelaskan informan Agus dan Rahmawati seperti dituturkan berikut proses penginputan data atau dokumen bahwa dalam :

"Itu mi yang harus di masukkan ke sistem komputer yang online untuk aplikasi e-planning sebagi dokumen untuk rencana pembangunan propinsi, memang membutuhkan dokumen-dokumen untuk di masukkan kedlam sistem. Seperti, RPJMD punya punya tanggung jawab itu Bappeda, untuk OPD-OPD itu harus menyiapkan Renstranya, DPD untuk dokumen Pokirnya. Untuk pemerintah kabupaten menyiapkan hasil musrembangnya sebagi bagian dari dokumendokumen yang harus di masukkan kesisitem. Oh iyya Program dan kegiatan tidak bisa diinput jika tidak termuat dalam Renstra yang telah diinput sebelumnya sehingga program penganggaran harus, mesti disesuaikan".

Proses penginputan data, selanjutnya dijadikan bahan informasi rancangan rencana kerja pihak Pemerintah Kabupaten melalui pelaksanaan pra-musrenbang yang tersedia pada aplikasi fitur e-planning. Website ini menyediakan fitur informasi untuk pelaksanaan pra-musrenbang dilakukan dengan pihak kabupaten, yang mana dari kabupaten akan menginput usulan rencana kerjanya kedalam aplikasi e-planning, yang kemudian dimonitor dan dikontrol Bappeda Provinsi untuk diarahkan pada setiap OPD berdasarkan fungsi dan kewenangan masing-masing. Setelah itu akan diverifikasi oleh setiap bidang teknis di OPD untuk menentukan usulan rencana kerja yang bisa atau tidak bisa diakomodir oleh pemerintah provinsi, hasil pembahasan itu akan dipaparkan dalam forum Musrenbang. Data-data dokumen disimpan dalam suatu sistem database. Sistem database ini memungkinkan proses menyimpan, mengedit, dan dapat diakses kapan saja.

\section{Monitoring dan Kontrol}

Monitoring dan kontrol dokumen-dokumen tersebut secara langsung melalui sistem $e$ planning untuk bisa dimonitoring, dikontrol, dan diverifikasi. Hasil varifikasinya oleh Bappeda diteruskan ke OPD untuk diteruskan ke kabupaten dalam suatu forum musrembang. Seperti dituturkan Fatimah berikut ini :

“...monitoringnya bisa langsung melalui sisitem komputer. Meskipun kadang dilakukan secara, dengan Simda Perencanaan verifikasi secara otomatis dengan sistem. Ini sangat membanty untuk mencek dan mengcocokkan setiap dokumen yang ada di dalam komputer. Supaya kami atau admin kami mengonyrol setiap dokumen yang telah ada di komputer. Seperti contoh, dokumen program dan kegiatan tidak bisa diinput jika tidak termuat dalam Renstra yang telah diinput sebelumnya......Pengusulan dari kabupaten melalui e-planning 


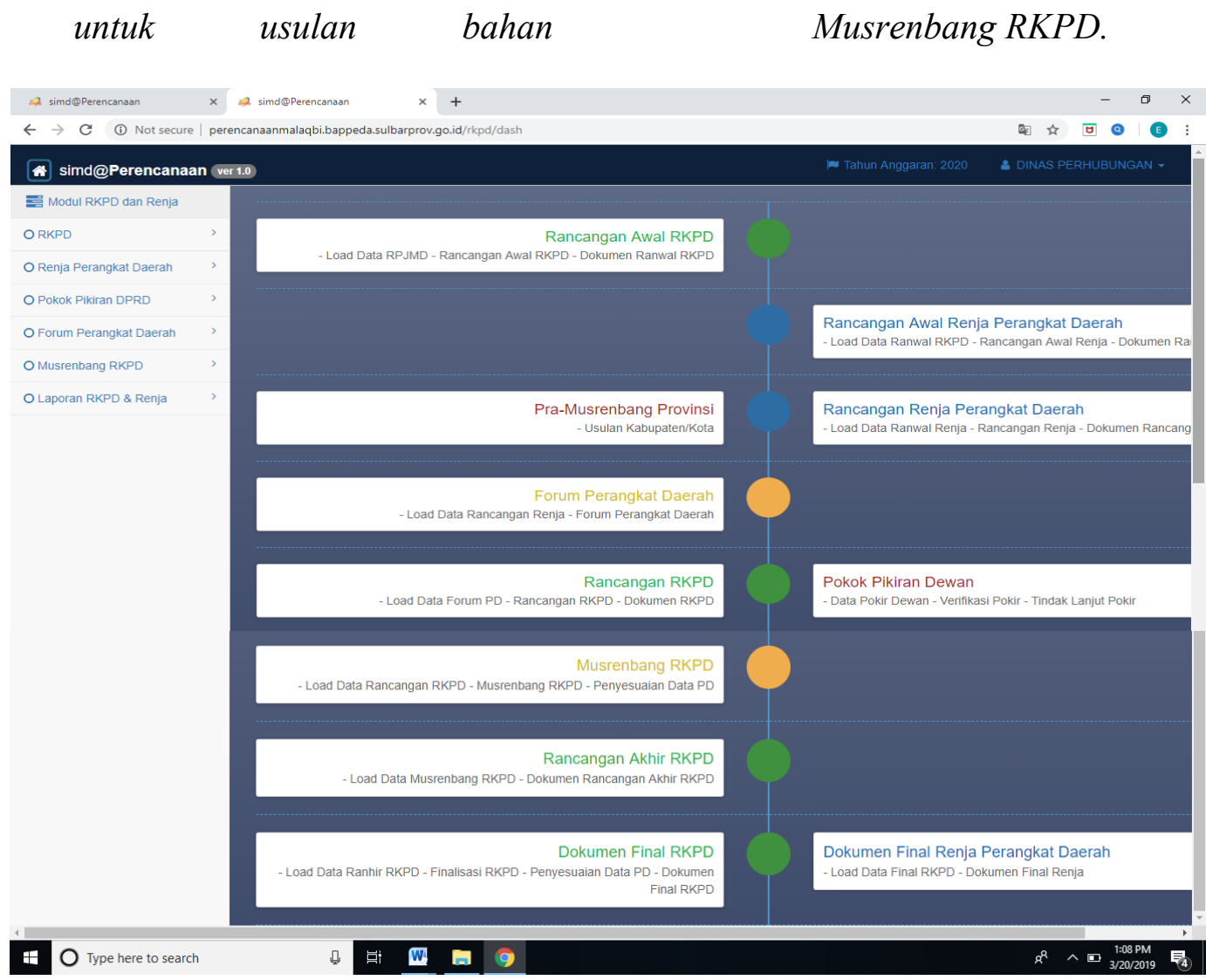

Sumber: http://bappedasulbar.eplanning9.com/masuk.php 2020

\section{Gambar 4 Fitur Pengontrolan dan Verifikasi}

Hal tersebut kemudian

monitoring dan kontrol oleh

pemerintah untuk mengetahui

tingkatan proritas rencana

pembangunan, berpedoman pada hasil verifikasi dan kontrol termasuk kelengkapan dokumen Renstra dan RPMJD. Hal ini sesuai dituturkan oleh informan Irman Latief :

...."dalam aplikasi e-planning, melalui fitur bisa dan selanjutnya diverifikasi untuk dimonitoring dan dikontrol oleh Bappeda dan OPD Provinsi yang akan menentukan status usulan dari Kabupaten tersebut diakomodir atau belum dapat diakomodir dengan alasan tertentu....misalnya untuk Pokir lebih mudah dikontrol dan dimonitoring disesuaikan dengan rencana kerja masing-masing $O P D$ yang akan dituangkan dalam RKPD...."

Dalam fitur website $e$ planning ini memiliki fitur komunikata yang diperuntukkan untuk melakukan koordinasi atau konsultasi, meski fitur ini masih memiliki keterbatasan ketika digunakan untuk komunikasi secara langsung karena admin ataupun operator di OPD tidak setiap saat mengaktifkan aplikasi $e$ planning, sehingga $C M C$ ini dalam pemanfaatannya belum efektif dalam membangun koordinasi yang baik.

3. Integratisasi Perencanaan dan Anggaran 
Kemudian untuk integrasi perencanaan dan anggran didasarkan pada RKPD untuk dibahas bersama legislatif dalam bentuk KUA-PPAS. Setelah dilakukanmusrembang provinsi untuk pembahasan Renja untuk dibawah ke forum legislatif untuk menentukan kegiatan-kegiatan proritas dan menghasilkan KUAPPAS sebagi pagu OPD untuk tahun pelaksanannya.

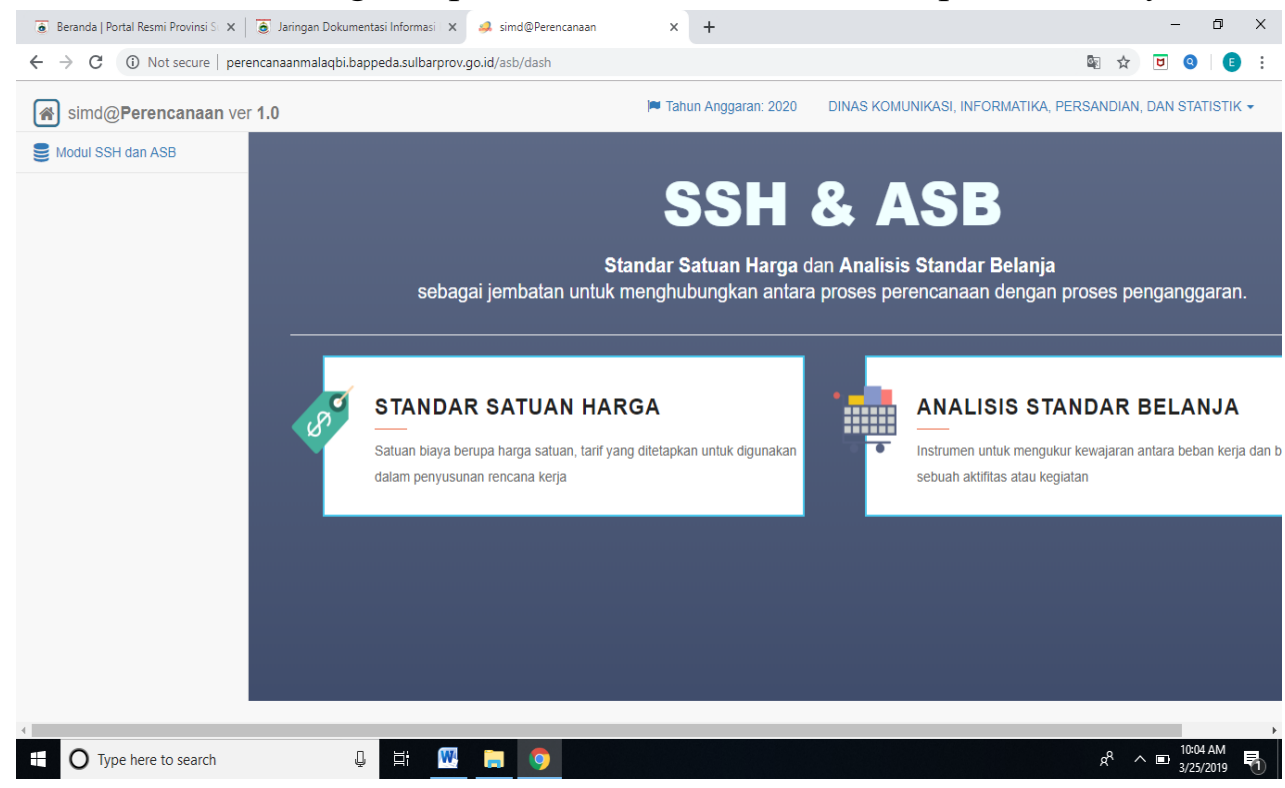

Sumber: http://bappedasulbar.eplanning9.com/masuk.php 2020

\section{Gambar 3 Fitur dan Aplikasi SSH dan ASB}

Pengembangan aplikasi $e$ planning, penyusunan Renja Awal sudah dapat dilakukan dengan terintegrasi antara perencanaan dan penganggaran sehingga akan mempercepat proses penyusunan rencana kegiatan beserta rencana anggaran yang akan dilaksanakan. Aplikasi website Simda Perencanaan (e-planning) yang memiliki fitur integrasi antara $e$ planning dan e-budgeting dan didukung fitur Standar Satuan Harga (SSH) dan Analisis Standar Belanja (ASB) dalam proses penyusunan perencanaan dan penganggaran yang transparan dan akuntabel, sehingga menghasilkan dokumen yang konsisten antara perencanaan dan penganggaran.
Proses ini dikembangkan terintegrasi dengan menggunakan media infromasi website $e$ budgeting untuk penyusuan anggran dan rencana. Hal ini seperti dijelaskan Imran Latief, sebagai berikut :

“.....selanjutnya e-planning terintegrasi e-budgeting memudahkan dalam proses Penentuan anggaran sementara dibahas bersama legislatif yang dituangkan dalam KUA-PPAS, transparan dan mudah dimonitor....Pokir lebih mudah disesuaikan dengan rencana kerja masing- masing OPD yang akan dituangkan dalam RKPD...Pada aplikasi SIPPD, verifikasi usulan rencana kegiatan berdasarkan indikator keluaran, indikator kegiatan, dan kesesuian dengan renstra 
dilakukan

secara

manual.....koneksitas

tersambung langsung antara Eplanning (SIPPD) hanya menginput renja awal, kemudian menjadi RKPD.....Untuk penganggaran menggunakan aplikasi lain yaitu simda keuangan...."

Fitur SSH dan ASB merupakan fitur baru dari aplikasi e-planning dalam penyusunan rencana kerja (Renja), dengan fitur ini akan memudahkan dalam penyusunan rencana kegiatan dalam menghitung secara otomatis jumlah anggaran yang dibutuhkan. Pada simda perencanaan diintegrasikan mulai dari perencanaan sampai penganggaran. Dengan aplikasi e-planning sebelumnya (SIPPD), setelah Renja diinput, dapat dicetak kemudian verifikasi hasil inputan ke Bappeda. Efisiensi pengintegrasian khususnya dalam penerapan $e$ planning dimulai saat penginputan dokumen oleh OPD diakunya dalam sistem itu akan langsung sampai tanpa ada waktu jeda. Selanjutnya, terbuka untuk diakses publik. Hanya terbatas untuk layanan pengaduan, publik bisa mengusulkan, kemudian Bappeda melalui bisa mengakses. Namun demikian, aplikasi Simda sekarang Bappeda belum menyediakan, tapi kedepannya akan menambah fasilitas itu, untuk saat ini belum ada ruang untuk publik mengakses informasi yang pemerintah lakukan atau rencanakan.

\section{Proses Finalisasi}

Tahapan sistem akhir, integritas data sistem e-planning dan e-budgeting berdasarkan dan merujuk pada output dokumen akhir RKPD dan Renja. Setelah melalui proses Musrembang dilaksanakan akan menghasilkan rancangan akhir RKPD dan Renja yang akan dibahas di DPRD sesuai dengan program dan kegiatan prioritas untuk ditetapkan menjadi dokumen final RKPD dan Renja Perangkat Daerah sebagai dokumen perencanaan program dan kegiatan pada tahun anggaran berikutnya. Proses umpan balik interaktif merupakan proses akhir penyusunan proritas perencanaan pembangunan dan pagu anggaran pelaksanaannya dan disahkan legislatif.

Pokok pikiran diinput rencana pembangunan ke dalam aplikasi, usulan anggota dewan diinput pada aplikasi e-planning. Seperti diutarakan informan Desiana Malino berikut ini:

“... dalam sisitem proses finalisasinya dokumen rancangan akhir RKPD dan Renja yang akan dibahas di di sidang DPRD sesuai dengan program dan kegiatan prioritas. Selanjutnya untuk ditetapkan menjadi dokumen final RKPD dan Renja Perangkat Daerah sebagai dokumen perencanaan program dan kegiatan pada Tahun Anggaran berikutnya....proses ini selanjutnya menjadi tugas pemerintah daerah untuk melaksanakannya ...." 
Dalam upaya mempermudah proses perencanaan bagi setiap pihak, maka diterapkannya $C M C$ dalam bentuk sistem perencanaan elektronik berbasis web memudahkan dalam proses pengambilan keputusan. $C M C$ dapat berperan dalam beberapa hal, yang paling pokok adalah dapat membantu menyebarluaskan informasi tentang dapat mengajarkan melek huruf serta keterampilan lainnya yang memang dibutuhkan untuk membangun masyarakat dan dapat menjadi penyalur suara masyarakat agar mereka turut ambil bagian dalam pembuatan keputusan di negaranya (Nasution, 2009:116).

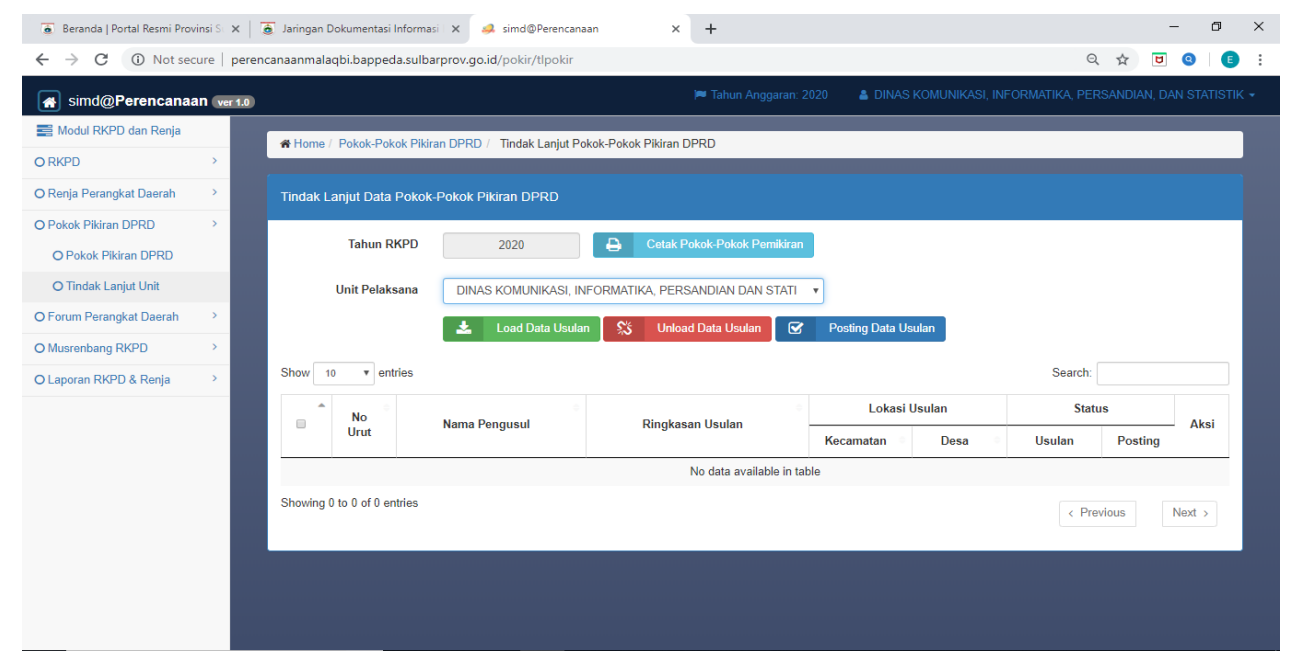

Sumber: http://bappedasulbar.eplanning9.com/masuk.php 2020

\section{Gambar 4 Aplikasi Fitur Pikiran DPRD}

Dengan demikian $C M C$ berbasis e-planning ini memiliki tujuan dalam proses penggunaanya yaitu sebagai media pengumpul informasi, seperti penginputan, pengkontrolan dan ferifikasi sampai pada proses pengambilan keputusan. Proses Pengolahan data diperoleh dari internal maupun eksternal kemudian diproses menjadi informasi. Data yang diolah setelah terkumpul dilakukan seleksi data, pengelompokan data dan perhitungan data sehingga muncul data akhir yang nantinya menjadi informasi yang berguna untuk kepentingan perencaanaan pembangunan. Dalam hal penyajian informasi $C M C$ diberikan kepada orang yang membutuhkan data tersebut. Tersimpan dengan baik agar semua informasi tersampaikan dengan jelas.

Penggunaan media $C M C$ berbasis website e-planning selangkah lebih maju dari ruang dan waktu, yang memungkinkannya untuk "asinkronisasi" dan secara 
geografis menggunakan secara bersama. Menggunakan teknologi ini dalam berkomunikasi antar berbagai pihak untuk pengambilan keputusan, dan proses pemecahan masalah. Teknologi yang mereka gunakan beragam, mulai dari berbagi dokumen sebagai lampiran email, hingga memposting informasi umum di website; menggunakan papan buletin elektronik dan blog; berbagi rekaman video dari presentasi informasi; dan menggunakan sesi obrolan komputer online, konferensi telepon, dan konferensi video Internet untuk melakukan diskusi publik.

Hal tersebut seperti dijelaskan Metzger dan Flanagan (2002) mememberikan penjelasan bahwa individu, secara umum, lebih aktif dalam penggunaan $C M C$ daripada ketika menggunakan media komunikasi yang lebih tradisional seperti buku, majalah, surat kabar, telepon, dan televisi. Komunikasi yang dimediasi komputer lebih diarahkan pada tujuan dan disengaja. $C M C$ untuk secara sengaja mencari jenis informasi dan hiburan tertentu daripada untuk menelusuri atau "menjelajahi web" secara santai hanya untuk menghabiskan waktu. Disebabkan CMC berbasis teks adalah sistem satu kode, yang hanya terdiri dari pesan tertulis yang melaluinya makna kontekstual. Tidak dimiliki saluran lain, misalnya, memiliki nama domain. Hosting berfungsi untuk menyimpan semua database (script, gambar, video, teks, dan lain sebagainya) dan konten berupa teks, gambar atau video. Database nya sebagai sumber data untuk fakta dan data, meskipun harus ditafsirkan dan diintegrasikan dengan bentuk dukungan lainnya. Seperti disebutkan dalam Thomas Harris \& John Sherblom (2008), CMC yang efektif; (1) mendorong tanggung jawab dan mempromosikan proses hasil kerja, (2) mengklarifikasi, dan mengintegrasikan informasi dan gagasan, (3) tepat waktu dan partisipasi; (4) informasi jelas, ringkas; (5) fleksibilitas, dan (6) membantu mencapai proses dan pengambilan keputusan.

\section{SIMPULAN}

Penggunaan CMC dalam perencanaan pembangunan daerah Provinsi Sulawesi Barat adalah melalui proses tahapan penginputan data dalam database, monitoring dan Kontrol dan integratisasi perencanaan dan Anggaran. E-planning terintegrasi e-budgeting dalam penentuan penganggaran dan membantu memberikan informasi dalam proses finalisasi penentuan pengambilan keputusan proritas pelaksanaan perencanaan pembangunan daerah berbasis kepentingan publik. Implikasi penelitian ini diharapkan memberikan ruang fitur diskusi publik untuk penyampaian aspirasi secara langsung dan fitur konsultasi publik dalam proses verifikasi perencanaan pembangunan daerah.

Impilikasi pengembangannya penelitian ini kedepan bahwa penggunaan $C M C$ dihubungkan aktivitas interaksi 
sosial berjaringan sehingga tidak cenderung bersifat individual bagi penggunannya. Rekomendasi diarahkan pada penelitian tentang penggunaan $C M C$ yang memberikan efek pengaruh sosial dalam membentuk persepsi-normatif sosial kemasyarakatan.

\section{UCAPAN TERIMA KASIH}

Ucapan terima kasih diberikan kepada pihak-pihak pihak yang terlibat secara langsung maupun tidak langsung, di antaranya; Kepala Dinas Komunikasi, Informatika, Persandian dan Statistik Provinsi Sulawesi Barat, Kepala Badan Perencanaan Pembangunan Daerah Provinsi Sulawesi Barat dan ASN lingkup Pemerintah Daerah Propinsi Sulwesi Barat terkhusus kepada pihak pengelolah aplikasi e-planning ini dalam memberikan informasi.

\section{DAFTAR PUSTAKA}

Aisyah1 \& Chandra, (2018).

Pemanfaatan Media Online

Beritajakarta.Id Dalam Publikasi

Program Kerja Pemprov Dki

Jakarta. Jurnal Avant Garde Vol. 6,

No. 2, Desember; $42-54$

Crispin Thurlow, Laura Lengel and Alice

Tomic, (2004). Computer Mediated

Communication. One Edition.

London; Sage Publication

Darma, J, S., \& Shenia, A. (2009). Buku

Pintar Menguasai Internet. Jakarta, Indonesia: Transmedia

Harry P, Edward F.T., Kalalo.Y. (2018) Ipteks Implementasi Perencanaan Pembangunan Daerah Berbasis EPlanning Pada Badan Perencanaan Dan Pembangunan Daerah (Bappeda) Sulawesi Utara. Jurnal
Ipteks Akuntansi Bagi Masyarakat, Vol. 02, No. 02, 2018, 11-15

Java Creatifity. (2014). Panduan Cerdas Membangun Website Super Keren. Jakarta; Elek Media Komputindo.

Kalalembang., (2019). E-Planning Dalam

Perencanaan Pembangunan Daerah

Pemerintah Provinsi Sulawesi

Barat. Tesis. Tidak Diterbitkan

McQuail, Denis. (2011). Teori Komunikasi Massa. Edisi 6 Buku 2. Terjemahan oleh Putri Iva Izzati. Jakarta : Salemba Humanika.

Metzger dan Flanagan (2002). Audience

Orientation toward new media. Communication Research Report. New York. SA Publishing

Mubarok, (2011). Determinisme

Teknologi Dan Posisi Media

Decenter Pada Kasus Pemberitaan

Kecelakaan Maut Di Tugu Tani Jakarta. Jurnal The Messenger, Volume III, Nomor 1.

Nasution, Zulkarimen. (2009). Komunikasi Pembangunan : Pengenalan Teori dan Penerapannya. (Edisi Revisi). Jakarta. Rajawali Pers.

Nugroho dan Saleh, F. (2019). Perancangan Media Komunikasi Berbasis Web Untuk Pembelajaran. Journal of Information Systems, Volume 5, Issues 2, October; 100105

Saptya M dan Mahameruaji, N.. (2019). Strategi Pemanfaatan Media Baru Net. TV Utilization of New Media Strategy Of Net.TV. Jurnal Studi Komunikasi Dan Media. Vol. 23 No. 1. Juni $2019: 21-36$

Sani, B. F., Harianto, H., \& Falatehan, A. F. (2019). Strategi Kesiapan Pemerintah Kota Bogor Dalam Penerapan Perencanaan 
Pembangunan Berbasis EPlanning. Jurnal Manajemen Pembangunan Daerah, 9(1).

Thurlow, C., Lengel, L., \& Tomic, A. (2004). Computer Mediated Communications: Social Interaction and The Internet. London, Inggris: SAGE Publication Ltd.

Thurlow, C., Lengel, L., \& Tomic, A. (2004). Computer Mediated Communications: Social Interaction and The Internet. London, Inggris: SAGE Publication Ltd.

Thomas Hauer. (2017). Technological

Determinism and New Media.

International Journal of English,

Literature and Social Science (IJELS). Vol-2, Issue-2, MaretApril; 1-4

Thomas Harris \& John Sherblom (2008).

Small Group and Team. Boston. Pearson Education, Inc

Zaonuddin. (2018). KPK Dorong Sulbar Integrasikan E-Planning dan EBudgeting. Dalam Antaranews.com. 2018. Dikutip dalam

https://makassar.antaranews.com/b erita/98779/kpk-dorong-sulbarintegrasikan-e-planning-dan-ebudgeting. Diakses Februari 2020

Wayan D. J. (2019). Sistem Perencanaan Pembangunan Terintegrasi Melalui Penerapan E-Planning (Studi Kasus pada Bappeda dan Litbang Kabupaten Gianyar). Jurnal Ilmiah Administrasi Publik Vol 5, No 3, pp 285-293.

Wijaya, Suryani. (2015). Perencanaan Dan Strategi Komunikasi Dalam Kegiatan Pembangunan. Jurnal Lentera, Vol. XVIII, No. 1, Juni; 53-60
Wong, Sabrina, (2007). Simulate Me: A Study of Computer-Mediated Communication in a Contemporary Society. Honors College. Theses. Dikutip dalam https://digitalcommons.pace.edu/honors college theses $/ 60 /$ ?utm source $=$ digitalc ommons.pace.edu\%2Fhonorscollege th eses\%2F60\&utm_medium=PDF\&utm_c ampaign $=$ PDFCoverPages 